\title{
Euro-optimism or euroscepticism: Opinions of students from Serbia, Macedonia and Bulgaria*
}

\author{
V. Miltojević \\ University of Niš \\ Čarnojevića 10a, Niš, Serbia, 18000 \\ (e-mail: vesna.miltojevic@znrfak.ni.ac.rs)
}

\begin{abstract}
The paper presents the opinions of students from two countries (Serbia and Macedonia) that strive to join the European Union and from one member country (Bulgaria) about the changes that brings the EU membership. These countries consider joining the European Union as a way out of the transition crisis, while the oldest member countries keep on talking about the decline in trust and euroscepticism. The research aims at identifying whether the students support the EU membership, believe in this community and in that the EU membership would contribute to changes in certain areas of social life; i.e. at identifying whether the students are euro-optimists or eurosceptics. The survey was conducted on a representative sample of 2,208 respondents in three university centers (Serbia - Niš, Macedonia Bitola, and Bulgaria - Veliko Tarnovo). The data show that, despite accepting the European integration in general, students do not trust in the European Union and do not expect any substantial changes, which makes them eurosceptics. However, there are differences between the three student samples. Thus, Macedonian students expect improvements in the economic development, employment, living standards and social security, but do not expect any significant changes in the quality of life, in reducing the gap between the rich and the poor and in preserving national identity and culture. Serbian students believe in the future economic growth and improving quality of the environment but think that all other areas of social life will remain unchanged. Bulgarian students say that the EU membership has not led to any changes and contributed to the higher unemployment rate and the larger gap between the rich and the poor.
\end{abstract}

Key words: European Union; euro-optimism; euroscepticism; soft euroscepticism; hard euroscepticism; students' opinions; surveys; Serbia; Macedonia; Bulgaria

Public opinion about the EU membership has changed over time and range from euro-optimism to euroscepticism due to the various economic, political, safety and other benefits and challenges from the EU membership [16]. Euro-optimism is defined as support of European integration and trust in the benefits of the EU membership. Euroscepticism and its indicators are defined differently. The term 'euroscepticism' was first used by Taggart two decades ago to define an open antago Nišm to the European integration [38. P. 366]. A few years later, Szczerbiak helped him to revise the initial definition to introduce a dichotomy of euroscepticisms - hard and soft: hard euroscepticism is an open antago Nišm to the European integration, while soft euroscepticism

* C V. Miltojević, 2019.

The research was financially supported by the Ministry of Education, Science and Technological Development of Serbia. Project No. 179074.

The article was submitted on 6.02.2019. 
implies rather an anxiety about changes in some areas of social life and in the position of the state [39. P. 7].

Other authors also worked on the definition of euroscepticism. Flood defines it as suspicion and mistrust in the EU and integration but distinguishes extreme and moderate skepticism [8. P. 550]. Leconte suggests a four-fold typology of euroscepticism: utilitarian, political, value-based and cultural. Utilitarian euroscepticism refers to the failure to get economic benefits from the EU membership at the individual or state level, while the political one expresses opposition or liberation from setting up a supranational institutional system; value-based euroscepticism refers to the opposition to the excessive intervention of the EU in value systems, and the cultural one ('anti-Europea Nišm') - to scepticism about Europe as a civilization, a historical-cultural entity [25]. Kopecky and Mudde believe that euroscepticism should be analyzed in two dimensions: diffuse and specific support. The first dimension consists of 'europhiles' (support the idea of the European integration) and europhobes (opponents of the idea), while another dimension includes eurooptimists (euroenthusiasts and europragmatics) and europessimists (eurosceptics and eurorejects). Eurosceptics support integration but not by means of today institutions, while eurorejects oppose the idea of integration [23. P. 300-302]. Attitude to the European integration and conceptualizations of euroscepticism were also examined by Lubbers and Sheepers [27], Sørensen [36] and many others.

Contrary to the original support of the European integration by the public and political elites $[13 ; 18]$, the research reveals changes in the attitudes to integration processes. Schmitt found out that such changes were determined by the increasing influence of the EU on national policies [33]; Arnold and Franklin, Hooghe and Marks explained the changes by the reduced autonomy of the peoples [1; 19]. The research after the 2008 economic crisis show the decline of public support for integration $[7 ; 32$; 37]; therefore, the issue of euroscepticism is addressed more often. To identify positive and negative attitudes, the researchers examined effects of various factors. Thus, Rohrschneider and Whitefield studied the relationship between euroscepticism and political parties [31], Bakker and de Vreese focused on the personality traits and opinions about the EU [3], Hakhverdian, van Elsas, van der Brug and Kuhn considered the relationship between education and euroscepticism [17]. The data show that among the reasons for the declining public support to integration, or for strengthening euroscepticism, are: the increasing influence of the EU on national policies [32] and the countries' decreasing autonomy [1]; slow recovery after the 2008 economic crisis [7; 24; 37]; personal attitudes to the European Union $[4 ; 20 ; 41]$; perception of political and territorial entities [41;42]; subjective economic estimates $[2 ; 9 ; 15 ; 22 ; 26]$, images of other cultures or minorities [29]; lack of democracy [14;35].

The studies of public opinion about the EU membership in post-socialist countries show that economic and political reforms are crucial factors for euro-optimism $[5 ; 6 ; 40]$. Since 1989, the Balkan countries have undergone the process of transition that led to structural and geopolitical changes. Three neighbouring post-socialist countries Serbia, Macedonia, and Bulgaria - face numerous economic, social, environmental and other challenges of transition, which makes them similar in that respect. According 
to the Human Development Index, three countries range from $59^{\text {th }}$ to $81^{\text {st }}$ ranks (Bulgaria - 59, Serbia - 64, Macedonia - 81), and the value of the HDI ranges from 0.782 (Bulgaria) and 0.771 (Serbia) to 0.747 (Macedonia). The GNI per capita in Serbia is 12.190, in Macedonia - 11.780, in Bulgaria - 15.596 [21]. However, despite their similarities, these countries differ by their EU status: Serbia and Macedonia are only candidates, Bulgaria is already a EU member.

The data presented in this paper are a part of the project Tradition, Modernization, and National Identity in Serbia and the Balkans under the European Integration and were collected in an empirical study "Cultural Orientations of Actors/Students, Interethnic Relations, National Identity, and Culture of Peace in the Balkans". The study aimed at identifying students' opinions on the quality of social changes in post-socialist societies under modernization, globalization and European integration [28. P. 30-31]. The original assumption was that students are euro-optimists, unconditioncally support the accession to the EU, demonstrate a high level of trust in the EU and expect positive changes in the economic development, employment, social security, living standards, environmental protection and preservation of national identity and culture. The study was conducted on the samples of students in the University of Niš (Serbia), University of Bitola (Macedonia), and St. Cyril and St. Methodius University of Veliko Tarnovo (Bulgaria). The representative sample consisted of 2,208 respondents: 818 - from the University of Niš, 804 - from the University of Bitola, and 586 - from the University of Veliko Tarnovo (all three universities are located in the second-largest cities of their countries) [30. P. 9-11]. A standardized questionnaire was used to get answers to the following questions: Do you approve of your country's EU accession/membership? To what extent do you believe in the European Union? Has the EU membership increased, preserved or decreased: economic growth, unemployment, standards of living, social security, the gap between the rich and the poor, environmental pollution, preservation of national identity and culture. The trust in the EU was examined with the help of the Likert scale.

$58 \%$ students approved of their countries' EU membership, $24.5 \%$ - did not approve, and $17.5 \%$ did not have any opinion. However, they expressed a high degree of distrust towards the EU, slightly less than half, $45.4 \%$ (22.1\% tend not to trust and $23.3 \%$ distrust). $37 \%$ have trust in the EU ( $8.1 \%$ firmly trust and $28.9 \%$ tend to trust). Students who approve of the EU membership have trust in it (53.3\%: 10.3\% firmly trust and $43 \%$ tend to trust); those who do not have any opinion on the membership demonstrated a significantly lower degree of trust (17.1\%), and the opponents of the membership - the lowest (12\%). The largest share of students who are against the EU membership have no trust (75.9\%: $49.6 \%$ distrust and $26.3 \%$ tend not to trust); and a high share of those who do not have any opinion also do not trust in the EU (53.1\%) but also over $30 \%$ of those who agree with the EU membership (10.3\% distrust and $19.7 \%$ tend not to trust).

The students thought that positive changes would occur only in the economic growth, while the EU membership would not significantly affect the unemployment rate, standards of living, social security, the gap between the rich and the poor, the state of the environment, and preservation of national identity and culture (Table 1). Within 
the group of respondents who approve of the EU accession, 59.1\% think that it will affect positively the economic growth. On the contrary, the highest share of respondents who are against the EU membership (46.4\%) or do not have any opinion (48.8\%) think that joining the EU will not affect the economic growth, $26.3 \%$ and $33.2 \%$ think that it will increase it, and $27.3 \%$ and $17.9 \%$ - that decrease it. The highest share of respondents who support the EU accession (40\%) believe that unemployment will decrease, $32 \%$ - that it will remain at the same level, $28 \%$ think that it will increase. The highest share of respondents who are against the EU membership (48.1\%) or have no opinion (52.4\%) believe that unemployment will remain at the same level. A third of respondents who oppose the EU membership (35.5\%) and a quarter of having no opinion (25\%) think that unemployment will increase, $16.4 \%$ and $22.6 \%$ - that it will decrease.

Table 1

Students' opinions on the EU accession and changes in society

\begin{tabular}{|l|c|c|c|}
\hline \multicolumn{1}{|c|}{ Spheres of life } & increased & unchanged & decreased \\
\hline Economic growth & $\mathbf{4 6 . 5 \%}$ & $37.3 \%$ & $16.2 \%$ \\
\hline Unemployment & $29.3 \%$ & $\mathbf{3 9 . 5 \%}$ & $31.1 \%$ \\
\hline Standards of living & $39.0 \%$ & $\mathbf{4 0 . 0} \%$ & $21.1 \%$ \\
\hline Social security & $38.5 \%$ & $\mathbf{4 6 . 7 \%}$ & $14.8 \%$ \\
\hline Gap between the rich and the poor & $38.5 \%$ & $\mathbf{4 7 . 7 \%}$ & $13.8 \%$ \\
\hline Environmental pollution & $27.9 \%$ & $\mathbf{3 8 . 3} \%$ & $33.8 \%$ \\
\hline Preservation of national identity and culture & $22.8 \%$ & $\mathbf{5 1 . 3} \%$ & $25.9 \%$ \\
\hline
\end{tabular}

The opinions about changes in the standards of living were similar to those about economic growth: more than a half of respondents who approved of the EU membership (50.7\%) associated it with the better standards of living, 35.9\% thought that the standards would remain the same, $13.4 \%$ — that they would decline. The majority of respondents who opposed the EU membership (44.2\%) or had no opinion $(47.6 \%)$ thought that the standards of living would remain unchanged, $37.4 \%$ and $23.7 \%$ expected them to decline. The belief that accession/membership will raise the standards of living was expressed by $18.5 \%$ of opponents of the EU membership and by $28.7 \%$ of not having any opinion.

Moreover, like in the above mentioned cases, there is a statistically significant relationship between (non-)approval of the EU membership and opinions about the changes in social security. The majority of respondents who approved of the EU membership (48.8\%) thought that social security would increase, while the majority of its opponents $(55.1 \%)$ or having no opinion $(55.4 \%)$ believed that social security would remain unchanged. A high share of respondents supporting the EU membership $(40.6 \%)$ believe that there will be no changes in social security, $10.7 \%$ think that it will decrease. Almost the same share of opponents of the EU membership think that social security will increase $(21.5 \%)$ or decrease $(23.4 \%)$. Moreover, the highest percentage of respondents who approved of the EU accession (47.9\%) or had no opinion $(55.7 \%)$ thought that the gap between the poor and the rich would remain the same, while the opponents $(50.7 \%)$ believed that economic inequality would increase. Among the respondents accepting membership, 34.6\% thought that inequality would increase, 
$17.5 \%$ - that it would remain at the same level. Regardless of their opinion on the EU accession, the majority of respondents thought that the level of environmental pollution would remain the same. And, finally, the highest share of students, regardless of their opinion on the EU membership, argue that the EU accession will not affect the preservation of national identity and culture. Students who accept membership (28\%) think that the preservation of national identity and culture will increase with it membership, while $42.8 \%$ of opponents of the EU membership believe that it will have negative impact on the national identity and culture $(29.4 \%$ of not having any opinion and $17.5 \%$ of supporters of the membership).

Thus, the data indicate that, regardless of the general support to the EU membership, students demonstrate a high degree of distrust to the EU, which can be explained by their opinions on the benefits of the EU membership: they think that there will be no changes except for the economic growth. Two thirds of students who do not approve of the membership have neither trust in the EU nor belief in economic growth, higher employment rate, living standards, social security, environmental quality; on the contrary, they think that the gap between the rich and the poor will increase. All the above points to the euroscepticism among students. Moreover, although the majority of respondents from all three samples approved of their country's EU accession/membership, this opinion is more typical for students from the University of Veliko Tarnovo as compared to the University of Bitola and University of Niš (Table 2). Such a high percentage of the EU membership approval in Veliko Tarnovo implies that the EU accession solved some urgent problemd; likewise, the approval rate among the students of Bitola and Niš indicates that they hope the EU accession will help their countries.

The majority of students approve of the EU membersip but only the minority trusts in the EU: $20.1 \%$ of students from Niš have trust in the EU, $42.3 \%$ from Bitola, and $54.3 \%$ from Veliko Tarnovo. The highest level of mistrust is among the students from Niš $(61.4 \%, 38.2 \%$ in Bitola and $32.3 \%$ in Veliko Tarnovo (Table 3).

Table 2

Differences in opinions on the EU accession/membership by universities

\begin{tabular}{|l|c|c|c|}
\hline \multicolumn{1}{|c|}{ University of } & Yes & No & No opinion \\
\hline Niš & $43.8 \%$ & $32.8 \%$ & $23.4 \%$ \\
\hline Bitola & $59.8 \%$ & $21.1 \%$ & $19.1 \%$ \\
\hline Veliko Tarnovo & $\mathbf{7 5 . 5 \%}$ & $17.4 \%$ & $7.1 \%$ \\
\hline
\end{tabular}

Table 3

Trust in the EU by universities

\begin{tabular}{|l|c|c|c|c|c|}
\hline \multicolumn{1}{|c|}{ University of } & Firmly trust & Tend to trust & $\begin{array}{c}\text { Cannot } \\
\text { answer }\end{array}$ & $\begin{array}{c}\text { Tend } \\
\text { not to trust }\end{array}$ & Distrust \\
\hline Niš & $2.5 \%$ & $17.6 \%$ & $18.5 \%$ & $22.9 \%$ & $38.5 \%$ \\
\hline Bitola & $13.7 \%$ & $28.6 \%$ & $19.4 \%$ & $22.5 \%$ & $15.7 \%$ \\
\hline Veliko Tarnovo & $8.5 \%$ & $45.8 \%$ & $13.5 \%$ & $20.2 \%$ & $12.1 \%$ \\
\hline
\end{tabular}


The ANOVA test, i.e. a single-factor analysis of variance, showed the impact of the residential factor on the level of trust in the EU. Students were divided into groups by countries (Serbia, Macedonia, Bulgaria) or by universities. There was a statistically significant difference in the level of trust in the EU by countries: $F(2,1789), p=0.000$, Eta square (0.13), which can be interpreted as an influence of the residential factor on the level of trust in the EU. Subsequent comparisons (using Tukey Post Hoc Tests) show a significant difference between the median values of the EU trust of the students from Serbia $(M=3.19, S D=0.87)$ compared to the students from Macedonia $(M=2.49$, $\mathrm{SD}=0.99)$ and from Bulgaria $(\mathrm{M}=2.41, \mathrm{SD}=0.84)$. The difference in the level of the EU trust among the students from Bulgaria and Macedonia is not statistically significant.

The initial assumption was that students of the University of Veliko Tarnovo would say that the EU membership had increased economic growth, standards of living, social security and preservation of national identity and culture, and had decreased unemployment, the gap between the rich and the poor and environmental pollution. However, the majority said that there were no changes in economic growth that remained at the level; a somewhat higher share agreed that the growth had increased. On the contrary, the majority from the University of Bitola and Niš believe that the EU accession would increase their country's economic growth; a smaller share think that the EU accession would not have any impact (Table 4).

Table 4

Students' opinions on the EU membership and societal changes

\begin{tabular}{|c|c|c|c|c|}
\hline Speres of life & Changes & Niš & Bitola & $\begin{array}{l}\text { Veliko } \\
\text { Tarnovo }\end{array}$ \\
\hline \multirow[t]{3}{*}{ Economic growth } & increased & $45.0 \%$ & $59.2 \%$ & $30.6 \%$ \\
\hline & unchanged & $42.2 \%$ & $29.2 \%$ & $41.7 \%$ \\
\hline & decreased & $12.8 \%$ & $11.6 \%$ & $27.7 \%$ \\
\hline \multirow[t]{3}{*}{ Unemployment } & increased & $19.8 \%$ & $28.0 \%$ & $45.1 \%$ \\
\hline & unchanged & $47.4 \%$ & $34.7 \%$ & $35.3 \%$ \\
\hline & decreased & $32.9 \%$ & $37.2 \%$ & $19.5 \%$ \\
\hline \multirow[t]{3}{*}{ Standard of living } & increased & $38.4 \%$ & $49.0 \%$ & $25.3 \%$ \\
\hline & unchanged & $47.5 \%$ & $29.6 \%$ & $44.0 \%$ \\
\hline & decreased & $14.1 \%$ & $21.4 \%$ & $30.7 \%$ \\
\hline \multirow[t]{3}{*}{ Social security } & increased & $37.9 \%$ & $46.0 \%$ & $28.2 \%$ \\
\hline & unchanged & $49.3 \%$ & $39.4 \%$ & $53.8 \%$ \\
\hline & decreased & $12.8 \%$ & $14.7 \%$ & $18.0 \%$ \\
\hline \multirow[t]{3}{*}{ The gap between the rich and the poor } & increased & $34.1 \%$ & $33.0 \%$ & $53.0 \%$ \\
\hline & unchanged & $53.6 \%$ & $45.8 \%$ & $41.7 \%$ \\
\hline & decreased & $12.3 \%$ & $21.2 \%$ & $5.4 \%$ \\
\hline \multirow[t]{3}{*}{ Environmental pollution } & increased & $24.8 \%$ & $27.9 \%$ & $32.5 \%$ \\
\hline & unchanged & $34.6 \%$ & $37.8 \%$ & $44.5 \%$ \\
\hline & decreased & $40.5 \%$ & $34.3 \%$ & $23.0 \%$ \\
\hline \multirow{3}{*}{$\begin{array}{l}\text { Preservation of national identity } \\
\text { and culture }\end{array}$} & increased & $15.9 \%$ & $32.3 \%$ & $19.3 \%$ \\
\hline & unchanged & $48.8 \%$ & $47.9 \%$ & $59.8 \%$ \\
\hline & decreased & $35.3 \%$ & $19.8 \%$ & $20.9 \%$ \\
\hline
\end{tabular}


Students' opinions on the EU membership and ecomic changes by universities

\begin{tabular}{|c|c|c|c|c|}
\hline \multirow[t]{2}{*}{ University of } & \multirow[t]{2}{*}{$\begin{array}{l}\text { Do you approve of your } \\
\text { country's EU membership? }\end{array}$} & \multicolumn{3}{|c|}{$\begin{array}{c}\text { Has the EU membership increased, preserved } \\
\text { or decreased the economic growth? }\end{array}$} \\
\hline & & increased & unchanged & decreased \\
\hline \multirow[t]{3}{*}{ Niš } & Yes & $68.1 \%$ & $28.8 \%$ & $3.1 \%$ \\
\hline & No & $23.8 \%$ & $50.9 \%$ & $25.3 \%$ \\
\hline & No opinion & $32.1 \%$ & $55.1 \%$ & $12.8 \%$ \\
\hline \multirow[t]{3}{*}{ Bitola } & Yes & $72.5 \%$ & $20.6 \%$ & $6.9 \%$ \\
\hline & No & $37.5 \%$ & $39.9 \%$ & $22.6 \%$ \\
\hline & No opinion & $41.1 \%$ & $44.4 \%$ & $14.6 \%$ \\
\hline \multirow{3}{*}{$\begin{array}{l}\text { Veliko } \\
\text { Tarnovo }\end{array}$} & Yes & $36.3 \%$ & $41.3 \%$ & $22.3 \%$ \\
\hline & No & $13.7 \%$ & $45.3 \%$ & $41.1 \%$ \\
\hline & No opinion & $9.8 \%$ & $36.6 \%$ & $53.7 \%$ \\
\hline
\end{tabular}

In terms of economic trends after joining the EU, the data indicate statistically significant differences by countries — between respondents from Niš, Bitola and Veliko Tarnovo, as well as between respondents from Bitola and Veliko Tarnovo. Students from Niš and Bitola that support the EU accession believe in economic prosperity after it. The largest share of the membership opponents and having no opinion think that the economic situation will not change. However, in Veliko Tarnovo the largest shares of respondents who approve and disapprove of Bulgaria's membership in the EU say that everything remained the same (Table 5).

The data reveal eurooptimism among students from Niš and Bitola that approve of the membership and trust in economic prosperity, while those who oppose it or have no opinion are considered as eurosceptics. Euroscepticism is present among the students of Veliko Tarnovo regardless of their opinion on the EU accession, perhaps due to the emphasis on the relationship between trust in the EU and economic prosperity.

The opinions of students from three countries about solving the problem of employment are different. Serbian students believe that the EU membership will not contribute to any changes in employment. On the contrary, Macedonian students express optimism and think that unemployment rate will fall, while Bulgarian students are pessimistic and believe that the EU membership contributed to the negative trend, and unemployment has increased. Students from Niš and Bitola who approve of their countries' membership in the EU express optimism and think that unemployment would decrease. Euroscepticism is typical for opponents of the EU membership and having no opinion - they think that unemployment would remain at the same level. However, regardless of whether they approve, disapprove or have no opinion on Bulgaria's EU membership, the largest share of students thought that unemployment had increased (Table 6).

$47.5 \%$ of students from the University of Niš did not associate Serbia's EU accession with the increased standards of living. Students from Veliko Tarnovo have similar opinion (44\% think that the standards will remain at the same level, 30.7\% — that will decrease, $25.3 \%$ - will increase). Students from Bitola have a completely different opinion: every second believes that the standards of living will increase (49\%) and less than $30 \%$ think that they will remain at the same level $(29.6 \%), 21.4 \%$ - that they will increase. Thus, students from Niš and Veliko Tarnovo are eurosceptics, while students from Bitola are eurooptimists. 
Students' opinions on the EU membership and unemployment by universities

\begin{tabular}{|l|l|c|c|c|}
\hline \multirow{3}{*}{ University of } & \multicolumn{2}{|c|}{$\begin{array}{c}\text { Do you approve of your } \\
\text { country's EU membership? }\end{array}$} & \multicolumn{2}{c|}{$\begin{array}{r}\text { Has the EU membership increased, preserved or de- } \\
\text { creased unemployment? }\end{array}$} \\
\cline { 3 - 5 } & & increased & unchanged & decreased \\
\hline \multirow{3}{*}{ Niљ } & Yes & $15.8 \%$ & $33.8 \%$ & $\mathbf{5 0 . 4 \%}$ \\
\cline { 2 - 5 } & No & $27.3 \%$ & $\mathbf{5 6 . 2} \%$ & $16.5 \%$ \\
\cline { 2 - 5 } & No opinion & $16.5 \%$ & $\mathbf{6 0 . 1} \%$ & $23.4 \%$ \\
\hline \multirow{3}{*}{ Bitola } & Yes & $26.2 \%$ & $26.8 \%$ & $\mathbf{4 7 . 0 \%}$ \\
\cline { 2 - 5 } & No & $31.5 \%$ & $\mathbf{4 6 . 4} \%$ & $22.0 \%$ \\
\cline { 2 - 5 } & No opinion & $28.5 \%$ & $\mathbf{4 7 . 0} \%$ & $24.5 \%$ \\
\hline \multirow{3}{*}{ Veliko Tarnovo } & Yes & $\mathbf{4 0 . 2} \%$ & $36.4 \%$ & $23.4 \%$ \\
\cline { 2 - 5 } & No & $\mathbf{6 4 . 9} \%$ & $28.9 \%$ & $6.2 \%$ \\
\cline { 2 - 5 } & No opinion & $\mathbf{5 1 . 2 \%}$ & $36.6 \%$ & $12.2 \%$ \\
\hline
\end{tabular}

Students' opinions on the EU membership and standards of living by universities

\begin{tabular}{|l|l|c|c|c|}
\hline \multirow{3}{*}{ University of } & \multicolumn{2}{|c|}{$\begin{array}{c}\text { Do you approve of your } \\
\text { country's EU membership? }\end{array}$} & \multicolumn{2}{|c|}{$\begin{array}{c}\text { Has the EU membership increased, } \\
\text { preserved or decreased standards of living }\end{array}$} \\
\cline { 3 - 5 } & & increased & unchanged & decreased \\
\hline \multirow{3}{*}{ Niš } & Yes & $\mathbf{6 1 . 7 \%}$ & $33.2 \%$ & $5.1 \%$ \\
\cline { 2 - 5 } & No & $15.0 \%$ & $\mathbf{5 9 . 0} \%$ & $25.9 \%$ \\
\cline { 2 - 5 } & No opinion & $27.8 \%$ & $\mathbf{5 7 . 8} \%$ & $14.4 \%$ \\
\hline \multirow{3}{*}{ Bitola } & Yes & $\mathbf{6 1 . 4 \%}$ & $26.8 \%$ & $11.7 \%$ \\
\cline { 2 - 5 } & No & $26.8 \%$ & $31.0 \%$ & $\mathbf{4 2 . 3} \%$ \\
\cline { 2 - 5 } & No opinion & $34.2 \%$ & $\mathbf{3 7 . 5} \%$ & $28.3 \%$ \\
\hline \multirow{3}{*}{ Veliko Tarnovo } & Yes & $29.4 \%$ & $\mathbf{4 8 . 3} \%$ & $22.3 \%$ \\
\cline { 2 - 5 } & No & $13.5 \%$ & $26.0 \%$ & $\mathbf{6 0 . 4 \%}$ \\
\cline { 2 - 5 } & No opinion & $12.2 \%$ & $39.0 \%$ & $\mathbf{4 8 . 8} \%$ \\
\hline
\end{tabular}

The majority of students from Niš and Bitola who support the EU accession associate it with higher standards of living. However, there is a difference between Serbian and Macedonian students who oppose the EU accession and have no opinion. The majority of such Serbian students think that the standards of living will remain the same; the highest share of students from Bitola who are against the EU membership think that the standards of living will fall, while not having any opinion do not expect changes here. Bulgarian respondents who support the EU membership think that their standards of living remained the same, while opponents and having no opinion mentioned a decline (Table 7). Such answers reveal euro-optimism of Serbian and Macedonian students and euroscepticism of Bulgarian students.

Although the majority of respondents think that social security will remain the same, the highest shares of Serbian and Bulgarian students believe that it will remain at the same level, while Macedonian students expect its growth. Euro-optimism is evident among students from Niš and Bitola who opt for the EU membership, while its opponents or having no opinion think that there will be no changes. Bulgarian students, regardless of their opinion on joining the EU, show euroscepticism in terms of social security (see no changes). Moreover, the majority of respondents from the non-EU universities think that the gap between the rich and the poor will remain 
the same after accession (Niš: 53.6\%, Bitola: 45.8\%), an almost equal number think that it will increase (Niš: $34.1 \%$, Bitola: $33 \%$ ). On the contrary, the majority of students from the University of Veliko Tarnovo think that the gap between the rich and the poor has increased due to Bulgaria's EU accession (53\%), 41.7\% consider it the same. The largest share of Serbian students, regardless of their opinion in the EU membership, think that the differences between the rich and the poor will remain the same. Regardless of their attitudes to Bulgaria's EU membership, students from Veliko Tarnovo believe that the gap has not decreased. Considering the students' opinions on the gap between the rich and the poor, all respondents, regardless thir country and opinions on the EU membership, are euroskeptics.

Finally, there are differences in the opinions of students on preserving national identity and culture. Although the largest shares in all three samples think that the EU membership will not affect the preservation of national identity and culture, among the students who support the membership or do not have any opinion, the largest share does not believe in changes, while Serbian students who are against the EU membership still believe in its positive impact on preserving national identity and culture (Table 8).

Students' opinions on the EU membership and preserving national identity and culture

\begin{tabular}{|l|l|c|c|c|}
\hline \multirow{3}{*}{ University of } & \multicolumn{1}{|c|}{$\begin{array}{c}\text { Do you approve of your } \\
\text { country's EU membership? }\end{array}$} & \multicolumn{2}{|c|}{$\begin{array}{r}\text { Has the EU membership increased, } \\
\text { preserved, or decreased preservation } \\
\text { of national identity and culture? }\end{array}$} \\
\cline { 3 - 5 } & & \multicolumn{2}{|c|}{$\begin{array}{r}\text { unchanged } \\
\text { decreased }\end{array}$} \\
\cline { 2 - 5 } & & $21.1 \%$ & $\mathbf{5 8 . 9} \%$ & $20.0 \%$ \\
\hline \multirow{3}{*}{ Niš } & Yes & $10.6 \%$ & $34.0 \%$ & $\mathbf{5 5 . 5 \%}$ \\
\cline { 2 - 5 } & No & $14.1 \%$ & $\mathbf{5 0 . 3} \%$ & $35.7 \%$ \\
\cline { 2 - 5 } & No opinion & $38.2 \%$ & $\mathbf{4 6 . 3} \%$ & $15.5 \%$ \\
\hline \multirow{3}{*}{ Bitola } & Yes & $22.6 \%$ & $\mathbf{5 0 . 0} \%$ & $27.4 \%$ \\
\cline { 2 - 5 } & No & $24.5 \%$ & $\mathbf{5 1 . 7 \%}$ & $23.8 \%$ \\
\cline { 2 - 5 } & No opinion & $22.3 \%$ & $\mathbf{6 0 . 0} \%$ & $17.8 \%$ \\
\hline \multirow{3}{*}{ Veliko Tarnovo } & Yes & $10.5 \%$ & $\mathbf{5 4 . 7 \%}$ & $34.7 \%$ \\
\cline { 2 - 5 } & No & $9.8 \%$ & $\mathbf{6 8 . 3} \%$ & $22.0 \%$ \\
\cline { 2 - 5 } & No opinion & & & \\
\hline
\end{tabular}

Considering the variability of opinions about social changes and the course of changes as determined by the EU accession, the ANOVA test, which was used to assess the impact of the residential factor on the social changes and their course, shows that the differences are not statistically significant: $F(2,2145), p=0.000$, Eta square $=0.07$.

The results of survey in Bulgaria somewhat surprised us. Subjective estimates of the benefits of the EU membership by students from Veliko Tarnovo in terms of economic growth do not correspond to the official data: the GNI per capita grows. Before the EU accession in 2007, it was 12.360, and in 2012 - 15.690, but thhis rise is not recognized (not visible or irregularly distributed). On the other hand, the unemployment rate was decreasing (from $18.2 \%$ in 2002 to the lowest rate of $5.6 \%$ in 2008) only to begin to grow again to reach $12.3 \%$ in 2012 with an ongoing increasing trend $[10 ; 11]$. The results collected in the Bulgarian samples are surprising for Bulgarian students, as compared to Macedonian and especially Serbian students, showed considerable trust in the EU. 
Based on the presented data, the hypothesis was confirmed partially: the comparative analysis showed both similarities and differences not only between respondents from the EU member (Bulgaria) and non-EU countries, but also between students from Serbia and Macedonia. The majority of students approved of the EU accession/membership; nevertheless, regardless of this consensus and the general believe that the EU accession would contribute to the economic growth, students think that the EU membership does not necessarily contribute to the growth of standards of living, preservation of national identity and culture and social security or to the decrease of unemployment, the gap between the rich and the poor, and environmental pollution; thus, there is a high level of mistrust in the EU.

In general students consider the EU accession/membership as a way to solve only some problems. Students of the University of Niš express euro-optimism regarding economic growth and environmental issues and euroscepticism - regarding social prosperity in Serbia, i.e. unemployment rate, standards of living, social security, and the gap between the rich and the poor. Students of the University of Bitola are eurooptimistic, except in terms of the gap between the rich and the poor and environmental issues: the majority believe that the EU accession will contribute to economic growth, lower unemployment rate, higher standards of living and social security but will not affect preservation of national identity and culture, i.e. Macedonian students are more euro-optimistic that Serbian students.

Students of the University of Veliko Tarnovo are sceptic about economic growth, standards of living, social security, preservation of national identity and culture and environmental pollution, and, most importantly, they are eurosceptics on unemployment and the gap between the rich and the poor. Such opinions partially correlate with the data on the quality of life: on a scale from 1 to 10 , the Bulgarians evaluated their standards of living with 4.7, the Serbs — with 5.3, and the Macedonians — with 5.8 [12]. Students from Niš and Bitola are more optimistic than students from Veliko Tarnovo, which can be explained by the fact that Bulgarian students have an experience of being a EU member country, while Serbian and Macedonian students are just expecting positive changes after their countries' EU accession. The majority of students from three countries accept the EU membership but at the same time express a high level of mistrust in the EU and doubt significant positive changes in their countries after the EU accession; therefore, they can be named 'soft eurosceptics'.

\section{References}

[1] Arnold C., Franklin M.N. Introduction: Issue congruence and political responsiveness. West European Politics. 2012; 35 (6).

[2] Anderson C.J. When in doubt, use proxies: Attitudes toward domestic politics and support for European integration. Comparative Political Studies. 1998; 31 (5).

[3] Bakker B.N., de Vreese C.H. Personality and European Union attitudes: Relationships across European Union attitude dimensions. European Union Politics. 2016: 17 (1).

[4] Carey S. Undivided loyalties: Is national identity an obstacle to European integration? European Union Politics. 2002; 3 (4).

[5] Cichowski R.A. Western dreams, eastern realities. Support for the European Union in Central and Eastern Europe. Comparative Political Studies. 2000; 33 (10). 
[6] Christin T. Economic and political basis of attitudes towards the EU in Central and East European countries in the 1990s. European Union Politics. 2005; 6 (1).

[7] de Vries C.E. Ambivalent Europeans? Public support for European integration in east and west. Government and Opposition. 2013; 48 (3).

[8] Efimovski S. Euroscepticism as theoretical concept. Sociologija. 2013; 55 (4) (In Serbian).

[9] Eichenberg R.C., Dalton R.J. Europeans and the European Community: The dynamics of public support for European integration. International Organization. 1993; 47 (4).

[10] Eurostat Yearbook 2012: Labour Market. http://ec.europa.eu/eurostat/en/web/productsstatistical-books/-/CH 052012 XLS.

[11] Eurostat Statistics Explained. European Commission. Available from: http://ec.europa.eu/ eurostat/statistics-explained/index.php/File:Unemployment_rate_2004-2015_(\%25)_new.png [Accessed 11 Decembre 2018].

[12] Eurofond: Quality of life in enlargement countries. Third European Quality of Life Survey. 2013. http://www.eurofound.europa.eu/sites/default/files/ef_publication/field_ef_document/ ef1350en8_0.pdf.

[13] Franklin $\bar{M}$., Marsh M. Uncorking the bottle: Popular opposition to European unification in the wake of Maastricht. Journal of Common Market Studies. 1994; 32 (4).

[14] Follesdal A., Hix S. Why there is a democratic deficit in the EU: A response to Majone and Moravcsik. Journal of Common Market Studies. 2006; 44.

[15] Gabel M., Whitten G.D. Economic conditions, economic perceptions, and public support for European integration. Political Behavior. 1997; 19 (1).

[16] Gabel M.J., Palmer H.D. Understanding variation in public support for European integration. European Journal of Political Research. 1995; 27 (1).

[17] Hakhverdian A., van Elsas E., van der Brug W., Kuhn T. Euroscepticism and education: A longitudinal study of twelve EU member states. Amsterdam; 2013.

[18] Hobolt S.B., Tilley J. Blaming Europe? Responsibility without Accountability in the European Union. Oxford University Press; 2014.

[19] Hooghe L., Marks G. A postfunctionlist theory of European integration: From permissive consensus to constraining dissensus. British Journal of Political Science. 2009; 39 (1).

[20] Hooghe L., Marks G. Does identity or economic rationality drive public opinion on European integration? Political Science and Politics. 2004; 37 (3).

[21] Human Development Report. United Nations Development Programme. 2016. http://hdr.undp.org/ en/69206.

[22] Ioannou D., Leblond P., Niemann A. European integration and the crisis: Practice and theory. Journal of European Public Policy. 2015; 22 (2).

[23] Kopecky P., Mudde C. The two sides of euroscepticism: Party positions on European integration in East Central Europe. European Union Politics. 2002; 3 (3).

[24] Lakićević D.D. Europe on the measure of the strong. Sociološki Pregled. 2013; XLVII (1) (In Serbian).

[25] Lecont C. Understanding Euroscepticism. New York; 2010.

[26] Lewis-Beck M. Economics and Elections: The Major Western Democracies. University of Michigan Press; 1990.

[27] Lubbers M., Scheepers P. Poitical versus instrumental euro-scepticism: Mapping scepticism in European countries and regions. European Union Politics. 2005; 6 (2).

[28] Mitrović Lj., Stojić G. Transition, Modernizations, and National Identity in Serbia and the Balkans under the European Integration (Road Map for the macro-project 179074). Niš; 2012 (In Serbian).

[29] McLaren L.M., Guera S. Public opinion and the European Union. Cini M., Pérez-Solórzano Borragán N. (Ed.). European Union Politics. Oxford University Press; 2013.

[30] Petrović J. Basic information on the sample, instrument, and field work for the empirical study "Cultural Orientation of Actors/Students, Interethnic Relations, National Identity and the Culture of Peace in the Balkans". Zaharijevski D.S., Djorić G., Stojić G. (Eds.). Cultural Orietations of Students and the Culture of Peace in the Balkans. Niš; 2014 (In Serbian). 
[31] Rohrschneider R., Whitefield S. Responding to growing European Union-skepticism? The stances of political parties toward European integration in Western and Eastern Europe following the financial crisis. European Union Politics. 2016; 17 (1).

[32] Roth F., Nowak-Lehmann F., Otter T. Crisis and trust in national and European Union institutions - panel evidence for the EU, 1999-2012. EUI Working Papers RSCAS 2013/31. http://cadmus.eui.eu/handle/1814/26975.

[33] Schmitt H. The European parliament elections of June 2004: Still second-order? West European Politics. 2005; 28 (3).

[34] Sørensen C. Public euroscepticism: The diversity of Denmark, France and the United Kingdom. https://www.eliamep.gr/wp-content/uploads/en/2008/10/sorensen_conceputalising_public_ euroscepticism.pdf.

[35] Sørensen C. Love me, love me not: A typology of public euroscepticism. SEI Working Paper No. 101. 2008. https://docplayer.net/41439918-Love-me-love-me-not-a-typology-of-publiceuroscepticism-catharina-sorensen-da Nišh-institute-for-international-studies.html.

[36] Sørensen C. Euroscepticism. A Conceptual Analysis and a Longitudinal Cross-Country Examination of Public Scepticism towards the European Union. PhD Thesis. Copenhagen; 2007.

[37] Serricchio F., Tsakatika M., Quaglia L. Euroscepticism and the global financial crisis. Journal of Common Market Studies. 2013; 51 (1).

[38] Taggart P. A touchstone of dissent: Euroscepticism in contemporary Western European party system. European Journal of Political Research. 1998; 33 (3).

[39] Taggart P., Szczerbiak A. Theorising party-based euroscepticism: Problems of definition, measurement and causality. SEI Working Paper No. 69. 2003. https://www.sussex.ac.uk/webteam/ gateway/file.php?name=epern-working-paper-12.pdf\&site $=266$.

[40] Tucker J.A., Pacek A.C., Berinsky A.J. Transitional winners and losers: Attitudes toward EU membership in post-commu Ništ countries. American Journal of Political Science. 2002; 46 (3).

[41] Van Kersbergen K. Political allegiance and European integration. European Journal of Political Research. 2000; 37 (1).

[42] Weßels B. Discontent and European identity: Three types of euroscepticism. Acta Politica. $2007 ; 42(2-3)$.

\title{
Еврооптимизм или евроскептицизм: мнения студентов Сербии, Македонии и Болгарии*
}

\section{В. Милтоевич}

\author{
Университет Ниша \\ ул. Чарноевича, 10а, Ниш, Сербия, 18000 \\ (e-mail: vesna.miltojevic@znrfak.ni.ac.rs)
}

В статье представлены мнения студенчества двух стран (Сербии и Македонии), которые стремятся стать членами Европейского Союза (ЕС), и одной страны (Болгарии), которая уже получила этот статус, о том, какие изменения способно обеспечить подобное членство. Все три страны считают вступление в ЕС способом преодолеть кризис переходного периода, однако многие старейшие члены

* C В. Милтоевич, 2019.

Исследование было проведено при финансовой поддержке Министерства образования, науки и технологического развития Республики Сербия. Проект № 179074.

Статья поступила в редакичию 6.02.2019. 
данного сообщества уверенно заявляют о падении доверия к нему и нарастании евроскептицизма. Исследование было призвано показать в сопоставительном ключе, поддерживают ли студенты вступление своих стран в ЕС, верят ли в силу данного сообщества и в то, что членство в нем обеспечит изменения в целом ряде важных сфер социальной жизни, т.е. проект должен был охарактеризовать студентов как еврооптимистов или евроскептиков. Опрос был проведен на репрезентативной выборке в 2208 респондентов в трех университетских центрах (в Сербии - в городе Ниш, в Македонии - в городе Битола, в Болгарии - в городе Велико-Тырново). Согласно полученным данным, несмотря на общее одобрение европейской интеграции, студенты все же не верят в потенциал ЕС и не ожидают от членства своих стран в нем каких-либо серьезных изменений в жизни своих обществ, что, несомненно, делает их евроскептиками. Однако между тремя студенческими выборками прослеживаются серьезные различия. Так, македонские студенты ожидают от членства своей страны в ЕС улучшений в сфере экономического развития, снижения уровня безработицы, повышения уровня жизни населения и социального обеспечения, однако не надеются на значительные изменения в качестве жизни, не ожидают сокращения разрыва в уровне доходов бедных и богатых и значительного вклада в сохранение своей национальной идентичности и культуры. Сербские студенты верят в будущий экономический рост и улучшение экологической ситуации, но полагают, что положение дел во всех остальных сферах общественной жизни не изменится. Болгарские студенты отмечают, что членство их страны в ЕС не принесло ей каких-либо серьезных изменений и даже усугубило проблему безработицы и увеличило разрыв в уровне жизни богатых и бедных.

Ключевые слова: Европейский Союз; еврооптимизм; евроскептицизм; мягкий евроскептицизм; жесткий евроскептицизм; мнения студентов; опросы; Сербия; Македония; Болгария 